Didaktik : Jurnal Pendidikan Guru Sekolah Dasar, ISSN : 24775673

Sekolah Tinggi Keguruan dan IImu Pendidikan Subang

Volume IV Nomor 2, Desember 2018

\title{
PENERAPAN METODE PEMBELAJARAN ROLE PLAYING UNTUK MENINGKATKAN SIKAP TOLERANSI KERAGAMAN SUKU BANGSA DAN BUDAYA KELAS V
}

\author{
Seli Marlia ${ }^{1}$, Aji Fauziana Ridwan², Asep Priatna ${ }^{3}$ \\ $1,2,3$ STKIP Subang \\ 1selimarlia.15@gmail.com
}

\begin{abstract}
This study is based on the problems found in the fifth grade of SD Negeri Rahayu, namely: (1) students' tolerance is still low; (2) the social studies learning process still takes place in a classical manner (Teacher Center); and (3) lack of utilization of learning models / methods. Thus the purpose of this study are: (1) to describe how the activities of students in learning the tolerance attitude of ethnic diversity and culture by applying the method of role playing; and (2) to describe an increase in the ability of tolerance of class $V$ students by applying the role playing method in learning. The research method used is Classroom Action Research (CAR) with the design of the Kemmis and MC models. Taggart is carried out for two cycles starting from the stages of planning, implementation, observation, and reflection. The subjects in this study were class V SD Negeri Rahayu 2018/2019 academic year, totaling 28 students. The instruments used to collect data in this study are: (1) observation sheet; and (2) questionnaire. The results of the study showed that: (1) in general the activities of fifth grade students in learning Social Sciences regarding the tolerance attitude of ethnic and cultural diversity experienced positive development. This is based on the average activity of students in the first cycle, which is 56\% and in the second cycle increases to $90 \%$; and (2) in general the increase in tolerance of ethnic groups and the culture of class $V$ students by using the role playing method in learning Social Sciences experienced positive development. This is based on N-Gain data in cycle I, o, 38 and in cycle II it increases to 0.58. The percentage completeness data obtained in the first cycle is $86 \%$, after reflecting and following up on cycle II it increases very well to $100 \%$.
\end{abstract}

Keywords: Role Playing Method, Tolerance Attitude, Classroom Action Research.

\begin{abstract}
ABSTRAK
Penelitian ini didasarkan pada permasalahan yang ditemukan di kelas V SD Negeri Rahayu yaitu: (1) sikap toleransi siswa masih rendah; (2) proses pembelajaran IPS masih berlangsung secara klasikal (Teacher Center); dan (3) kurangnya pemanfaatan model/metode pembelajaran. Dengan demikian tujuan penelitian ini yaitu: (1) untuk mendeskripsikan bagaimana aktivitas siswa dalam pembelajaran sikap toleransi keragaman suku bangsa dan budaya dengan penerapan metode role playing; dan (2) untuk
\end{abstract}


mendeskripsikan peningkatan kemampuan sikap toleransi siswa kelas $\mathrm{V}$ dengan penerapan metode role playing dalam pembelajaran. Metode penelitian yang digunakan adalah Penelitian Tindakan Kelas (PTK) dengan desain model Kemmis dan MC. Taggart yang dilakukan selama dua siklus yang dimulai dari tahap perencanaan, pelaksanaan, pengamatan (observasi), dan refleksi. Subjek dalam penelitian ini yaitu kelas V SD Negeri Rahayu tahun ajaran 2018/2019 yang berjumlah 28 siswa. Instrumen yang digunakan untuk mengumpulkan data dalam penelitian ini yaitu: (1) lembar observasi; dan (2) angket. Hasil penelitian menunjukkan bahwa: (1) secara umum aktivitas siswa kelas V dalam pembelajaran IImu Pengetahuan Sosial mengenai sikap toleransi keragaman suku bangsa dan budaya mengalami perkembagan poitif. Hal ini didasarkan pada rata-rata aktivitas siswa pada siklus I yaitu $56 \%$ dan pada siklus II menungkat menjadi $90 \%$; dan (2) secara umum peningkatan sikap toleransi keragaman suku bangsa dan budaya siswa kelas $\mathrm{V}$ dengan menggunakan metode role playing dalam pembelajaran IImu Pengetahuan Sosial mengalami perembangan positif. Hal ini didasarkan pada data N-Gain pada siklus I yaitu 0,38 dan pada siklus II meningkat menjadi 0,58 . Adapun data persentase ketuntasan yang diperoleh pada siklus I yaitu $86 \%$, setelah melakukan refleksi dan menindaklanjuti pada siklus II meningkat sangat baik menjadi $100 \%$.

Kata Kunci: Metode Role Playing, Sikap Toleransi, Penelitian Tindakan Kelas.

\section{A. Pendahuluan}

Pendidikan

kebutuhan pokok dalam menunjang kehidupan manusia. Setiap manusia berhak dan wajib mengikuti pendidikan agar dapat mengembangkan semua aspek pengetahuan, perkembangan, dan kepribadian manusia. Hak dan Kewajiban Warga Negara Indonesia Pasal 31 UUD 1945 Bidang Pendidikan. Pasal 31 Ayat 1 UUD 1945, dijelaskan bahwa: Setiap warga negara berhak mendapat pendidikan, dan Pasal 31 Ayat 2 UUD 1945, dijelaskan bahwa: Setiap warga negara wajib mengikuti pendidikan dasar dan pemerintah wajib membiayainya.

Pendidikan dalam arti luas merupakan usaha manusia untuk meningkatkan kesejahteraan

hidupnya, yang berlangsung sepanjang hayat. Henderson (Sadulloh, 2015:55) mengemukakan:

"But to see education as a process of growth and development talking place as the result of the interaction of an individual with his environment, both physical and social, beginning at birth and lasting as long as life it self a process in which the social heritage as a part of the social environment becomes a tool to be used toward the development. Of the best and most intelligent person possible, men and women who will promote human welfare, that is to see the educative process as philosophers and 
educational

conceived it".

Menurut Henderson di atas dapat disimpulkan, pendidikan merupakan suatu proses pertumbuhan dan perkembangan, sebagai hasil interaksi individu dengan lingkungan sosial dan lingkungan fisik, berlangsung sepanjang hayat sejak manusia lahir. Warisan sosial merupakan bagian dari lingkungan masyarakat,yang merupakan alat bagi manusia untuk pengembangan manusia yang terbaik dan intelejen, untuk meningkatkan kesejahteraan hidupnya.

Menurut Mudyahardjo (2002:6) secara simplistik, pendidikan didefinisikan sebagai sekolah, yakni pengajaran yang dilaksanakan atau diselenggarakan di sekolah sebagai lembaga pendidikan formal. Dalam undangundang Sistem Pendidikan Nasional No. 20 Tahun 2003, dijelaskan bahwa:

Pendidikan adalah usaha sadar dan terencana untuk mewujudkan suasana belajar dan proses pembelajaran agar peserta didik secara aktif mengembangkan potensi dirinya untuk memiliki kekuatan spiritual keagamaan, pengendalian diri, kepribadian, kecerdasan, akhlak mulia serta keterampilan yang diperlukan dirinya, masyarakat, bangsa dan negara.

Maka dari itu dapat disimpulkan bahwa pendidikan merupakan cara yang paling efektif dan strategis untuk membina karakter, mengangkat harkat dan martabat serta menyadarkan langsung akan dirinya sebagai khalifah Allah di bumi ini (Majid, 2014:4). Istilah "IImu Pengetahuan Sosial", disingkat IPS merupakan nama mata pelajaran di tingkat sekolah dasar, menegah dan atas, serta nama program studi di perguruan tinggi yang identik dengan istilah "Social Studies". Nama IPS lebih di kenal dengan Social Studies di negara lain itu merupakan istilah hasil kesepakatan dari para ahli dan pakar kita di Indonesia. Charles R. Keller (Kartika, 2017) mengatakan bahwa:

IPS adalah sebagai suatu paduan daripada sejumlah ilmu-ilmu sosial dan ilmu lainnya yang tidak terikat oleh ketentuan disiplin/struktur ilmu tertentu melainkan bertautan dengan kegiatankegiatan pendidikan yang berencana dan sistematis untuk kepentingan program pengajaran sekolah dengan tujuan memperbaiki, mengembangkan dan memajukan hubunganhubungan kemanusiaankemasyarakatan.

A. Kosasik Djahiri (Anshori, 2014) berpendapat, IPS adalah pelajaran yang merupakan suatu pelajaran yang menggunakan bagian-bagian tertentu dari ilmuilmu sosial. Menurut Ischak, S.U. (Anshori, 2014), IPS adalah bidang 
studi yang mempelajari, menelaah, menganalisis gejala dan masalah sosial di masyarakat dengan meninjau dari berbagai aspek kehidupan atau suatu perpaduan. IPS yang diajarkan di sekolah dasar menjadi dasar pengantar untuk mempelajari IPS yang lebih mendalam dijenjang sekolah yang lebih tinggi.

A. Azis Wahab (Anshori, 2014) IPS adalah sejumlah konsep mata pelajaran sosial dan ilmu lainnya yang dipadukan berdasarkan prinsip-prinsip pendidikan yang bertujuan membahas masalah sosial atau bermasyarakat dan kemasyarakatan untuk mencapai tujuan khusus pendidikan melalui pengajaran IPS pada tingkat persekolahan.

Pendapat-pendapat yang telah dikemukakan di atas maka disadari bahwa IPS adalah sebagai salah satu mata pelajaran yang berupaya untuk mengembangkan kompetensi sebagai warga negara yang baik. Warga negara yang baik berarti yang dapat menjaga keharmonisan hubungan di antara masyarakat sehingga terjalin persatuan dan keutuhan bangsa. Hal ini dapat dibangun apabila dalam diri setiap orang terbentuk perasaan yang menghargai/toleransi terhadap segala keanekaragaman, baik itu perbedaan pendapat, etnik, agama, kelompok, suku, budaya, bahasa, dan sebagainya. Bersikap terbuka dan senantiasa memberikan kesempatan yang sama bagi setiap orang atau kelompok untuk dapat mengembangkan dirinya. Oleh karena itu, pendidikan IPS memiliki tanggung jawab untuk dapat melatih peserta didik dalam membangun sikap toleransi.

Konsep pembelajaran IPS sebagai program pendidikan, tidak hanya menyajikan pengetahuan sosial semata, melainkan juga membina peserta didik menjadi warga negara yang memiliki tanggung jawab antara kesejahteraan bersama. Peserta didik yang dibinanya tidak hanya cukup berpengetahuan dan berkemampuan berpikir tinggi, melainkan harus pula memiliki kesadaran yang tinggi serta tanggung jawab yang kuat terhadap kesejahteraan masyarakat, bangsa dan negara. Maka kompetensi dasar yang disajikan, tidak terbatas pada materi yang berorientasi pada pengetahuan, melainkan juga meliputi nilai-nilai yang harus melekat pada diri peserta didik sebagai warga masyarakat dan warga negara.

Mata pelajaran IPS merupakan salah satu mata pelajaran yang diberikan di Sekolah Dasar yang mengkaji seperangkat peristiwa, fakta, konsep, dan generalisasi yang berkaitan dengan masalah-masalah sosial. Mata pelajaran IPS juga mencakup pada materi geografi, sejarah, sosiologi, dan ekonomi. Melalui mata 
pelajaran IPS, anak diarahkan untuk dapat menjadi warga negara Indonesia yang demokratis, bertanggung jawab, bermanfaat bagi bangsa dan negara serta menjadi warga dunia yang cinta damai. Ruang lingkup dalam mata pelajaran IPS di SD meliputi hal-hal yang berkaitan dengan (a) manusia, tempat, lingkungan, (b) waktu, keberlanjutan, dan perubahan (c) sistem sosial dan budaya, (d) perilaku ekonomi dan kesejahteraan. Tujuan pembelajaran IPS yang tertera pada Kurikulum Tingkat Satuan Pendidikan 2006 (Kartika, 2017), bahwa mata pelajaran IPS bertujuan agar peserta didik memiliki kemampuan sebagai berikut:

1) Mengenal konsep-konsep yang berkaitan dengan kehidupan masyarakat dan lingkungannya;

2) Memiliki kemampuan dasar untuk berpikir logis dan kritis, rasa ingin tahu, menemukan, memecahkan masalah, dan keterampilan dalam kehidupan sosial;

3) Memiliki komitmen dan kesadaran terhadap nilai-nilai sosial dan kemanusiaan; dan

4) Memiliki kemampuan berkomunikasi, bekerjasama, dan berkompetensi dalam masyarakat yang majemuk, di tingkat lokal, nasional, dan global.

Tujuan pembelajaran IPS menurut Kosasih Djahiri (Kartika,
2017) dalam bukunya "The Social Science Education Frame Work for California School" bahwa:

1) Membina siswa agar mampu mengembangkan pengertian/ pengetahuan berdasarkan data, generalisasi serta konsep ilmu tertentu maupun yang bersifat interdisipliner/komprehensif dari berbagai cabang ilmu sosial;

2) Membina siswa agar mampu mengembangkan dan mempraktekkan

keanekaragaman keterampilan studi, kerja dan intelektualnya secara pantas dan tepat sebagimana diharapkan ilmuilmu sosial;

3) Membina dan mendorong siswa untuk memahami, menghargai dan menghayati adanya keanekaragaman dan kesamaan kultural maupun individual;

4) Membina siswa ke arah turut mempengaruhi nilai-nilai kemasyarakatan serta dapat mengembangkan-

menyempurnakan nilai-nilai yang ada pada dirinya; dan

5) Membina siswa untuk berpartisipasi dalam kegiatan kemasyarakatan baik sebagai individu maupun sebagai warga negara.

Pendapat lain, Benjamin S. Bloom (Anshory, 2014), membagi tujuan pembelajaran IPS ke dalam tiga bidang yang disebut dengan Taksonomi Bloom, yaitu:

1) Aspek kognitif mencakup
perilaku-perilaku 


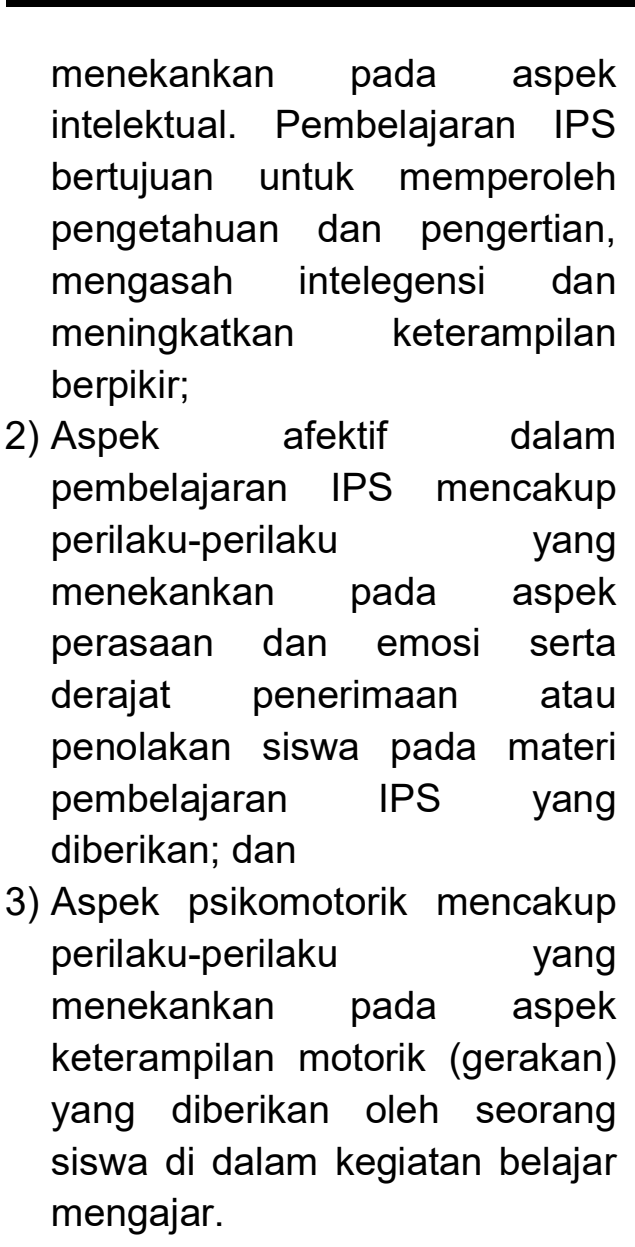

Tujuan-tujuan pembelajaran menurut para ahli di atas maka dapat disimpulkan bahwa tujuan pembelajaran IPS adalah mencakup pada tiga aspek yaitu kognitif, afektif dan psikomotor yang secara keseluruhan bertujuan untuk membina, mendorong, dan mengembangkan pengetahuan dan pemahaman peserta didik sehingga dapat mengubah perilaku-perilaku yang negatif kearah perilaku yang positif dan menjadi warga negara yang bertanggung jawab.

Berkaitan dengan tujuan pembelajaran IPS maka terdapat pula Karakteristik Pembelajaran IPS sebagaimana dikemukakan oleh A. Kosasih Djahiri (Anshori, 2014) bahwa:

1) IPS berusaha mempertautkan teori ilmu dengan fakta atau sebaliknya (menelaah fakta dari segi ilmu);

2) Penelaahan dan pembahasan IPS tidak hanya dari satu bidang disiplin ilmu saja, melainkan bersifat komprehensif (meluas/dari ilmu sosial dan lainnya, sehingga berbagai konsep ilmu secara terintegrasi terpadu) digunakan untuk menelaah satu masalah/tema/topik;

3) Pengutamakan peran aktif peserta didik melalui proses belajar inquiri agar peserta didik mampu mengembangkan berpikir kritis, rasional dan analitis;

4) Program pembelajaran disusun dengan

meningkatkan/menghubungkan bahan-bahan dari berbagai disiplin ilmu sosial dan lainnya dengan kehidupan nyata dimasyarakat, pengalaman, permasalahan, kebutuhan kepada kehidupan dimasa depan baik dari lingkungan fisik/alam maupun budayanya;

5) IPS dihadapkan secara konsep dan kehidupan sosial yang sangat labil (mudah berubah), sehingga titik berat pembelajaran adalah terjadi proses internalisasi secara 
mantap dan aktif pada diri peserta didik agar memiliki kebiasaan dan kemahiran untuk menelaah permasalahan kehidupan nyata pada masyarakatnya;

6) IPS mengutamakan hal-hal, arti dan penghayat hubungan antar manusia yang bersifat manusiawi;

7) Pembelajaran tidak hanya mengutamakan pengetahuan semata, juga nilai dan keterampilannya;

8) Berusaha untuk memuaskan setiap peserta didik yang berbeda melalui program maupun pembelajarannya dalam arti memperhatikan minat peserta didik dan masalahmasalah kemasyarakatan yang dekat dengan kehidupannya; dan

9) Dalam pengembangan program pembelajaran senantiasa melaksanakan prinsip-prinsip karakteristik (sifat dasar) dan pendekatan-pendekatan yang menjadi ciri IPS itu sendiri.

Karakteristik pembelajaran IPS ini mengutamakan hal-hal, arti dan penghayatan terhadap lingkungan sosial yang fakta atau real untuk menelaah suatu masalah-masalah kehidupan bermasyarakat sesuai pengalaman permasalahan dikehidupan sehariharinya baik berupa perbedaan pendapat, kebutuhan ekonomi, budaya, dan lain-lain. Selain itu, masalah pembelajaran IPS ini juga bersifat meluas atau komprehensif, sehingga dibutuhkan suatu pemikiran yang analitis, rasional, dan kritis.

Karakteristik pembelajaran IPS merupakan teori bagaimana membina kecerdasan sosial yang mampu berpikir kritis, kreatif, inovatif, berwatak dan berkepribadian luhur, bersikap ilmiah dalam cara memandang, menganalisa serta menelaah kehidupan nyata yang dihadapinya. Oleh karena itu, para pendidik dituntut untuk mampu merangsang dan merencanakan pembelajaran IPS sedemikian rupa dengan memperhatikan prinsip dan karakteristik IPS itu sendiri sehingga tujuan pembelajaran IPS dapat tercapai. IPS yang diajarkan di sekolah dasar menjadi dasar pengantar untuk mempelajari IPS yang lebih mendalam dijenjang sekolah yang lebih tinggi. Pada prinsipnya pendidikan IPS di sekolah dasar tidak mengajarkan ilmu-ilmu sosial sebagai disiplin ilmu, melainkan konsep-konsep esensi ilmu-ilmu sosial untuk membentuk siswa menjadi warga negara yang baik (good citizen).

IPS mempunyai tugas mulia dan menjadi pondasi penting bagi pengembangan intelektual, emosional, kultural dan sosial peserta didik, yaitu mampu menumbuh kembangkan cara berfikir, bersikap, dan berperilaku yang bertanggung jawab selaku 
individual, warga masyarakat, warga Negara, dan warga dunia. Selain itu IPS pun bertugas mengembangkan potensi peserta didik agar peka terhadap masalah sosial yang terjadi di masyarakat, memiliki sikap mental positif untuk perbaikan segala ketimpangan, dan terampil mengatasi setiap masalah yang terjadi sehari-hari baik yang menimpa dirinya sendiri maupun di masyarakat. Tujuan tersebut dapat dicapai manakala program-program pelajaran IPS di sekolah diorganisasikan secara baik.

Kondisi pembelajaran IPS dewasa ini khususnya pada jenjang sekolah dasar, menunjukan bahwa pola pembelajaran yang dikembangkan oleh guru cenderung lebih bersifat guru sentris atau berlangsung secara klasikal (Teacher Center) dan guru lebih sering menggunakan model pembelajaran konvensional yang lebih banyak diwarnai dengan ceramah, sehingga kurang mampu merangsang siswa untuk terlibat secara aktif dalam proses belajar mengajar. Hal tersebut kurang merangsang dan mendorong siswa untuk dapat mengembangkan nilainilai menghargai/sikap toleransi karena siswa tidak terlibat secara langsung dalam proses pembelajaran.

Pembelajaran IPS di sekolah dasar hendaknya lebih menekankan pada unsur pendidikan dan pembekalan pemahaman, nilai-moral, dan keterampilan-keterampilan sosial pada siswa. Untuk itu penekanan bukan hanya sebatas upaya menjejali siswa dengan sebuah konsep yang bersifat hapalan, melainkan terletak pada upaya menjadikan siswa memiliki seperangkat pengetahuan sikap, nilai, dan keterampilan. Karena manusia dalam kehidupannya selain sebagai makhluk individual juga merupakan makhluk sosial yang selalu berhubungan atau berinteraksi dengan manusia lainnya. Salah satu nilai yang perlu dikembangkan dalam interaksi sosial baik dalam kegiatan pembelajaran yaitu nilai menghargai/toleransi.

Mengacu kepada keputusan Komisi Internasional bagi pendidikan abad 21 yang di bentuk oleh UNESCO (Listanti, 2016), bahwa terdapat empat pilar pendidikan yaitu learning to know, learning to do, learning to be, dan learning to live together. Learning to know (belajar mengetahui), pendidikan pada hakikatnya merupakan usaha untuk mencari agar mengetahui informasi yang dibutuhkan dan berguna bagi kehidupan. Belajar untuk mengetahui (learning to know) dalam prosesnya tidak sekedar mengetahui apa yang bermakna tetapi juga sekaligus mengetahui apa yang tidak bermanfaat bagi kehidupannya. Learning to be (belajar melakukan sesuatu), 
pendidikan juga merupakan proses belajar untuk bisa melakukan sesuatu (learning to do). Proses belajar menghasilkan perubahan dalam ranah kognitif, peningkatan kompetensi, serta pemilihan dan penerimaan secara sadar terhadap nilai, sikap, penghargaan, perasaan, serta kemauan untuk berbuat atau merespon suatu stimulus. Pendidikan membekali manusia tidak sekedar untuk mengetahui, tetapi lebih jauh untuk terampil berbuat atau mengerjakan sesuatu sehingga menghasilkan sesuatu yang bermakna bagi kehidupan. Learning to be (belajar menjadi sesuatu), penguasaan pengetahuan dan keterampilan merupakan bagian dari proses menjadi diri sendiri (learning to be). Hal ini erat sekali kaitannya dengan bakat, minat, perkembangan fisik, kejiwaan, tipologi pribadi anak serta kondisi lingkungannya. Learning to live together (belajar hidup bersama), pada pilar keempat ini, kebiasaan hidup bersama, saling menghargai, terbuka, memberi dan menerima perlu dikembangkan disekolah. Kondisi seperti inilah yang memungkinkan tumbuhnya sikap saling pengertian antar ras, suku, dan agama.

Empat pilar pendidikan tersebut diharapkan peserta didik mampu memahami arti hidup dan tahu apa yang baik untuk dilakukan (Listanti, 2016). Peserta didik dapat memahami arti hidup orang lain dengan

saling menghargai/toleransi tentang adanya saling ketergantungan sehingga dapat menciptakan lingkungan yang aman dan nyaman khususnya di lingkungan sekolah, namun pada kenyataannya saat peneliti melakukan observasi ke SDN Negeri Rahayu tidak semua peserta didik merasakan hal demikian. Rasa kurang nyaman di lingkungan sekolah muncul dari teman sebaya diakibatkan oleh kurangnya sikap toleransi antar teman. Perilaku tersebut dapat berakibat melakukan tindakan secara fisik maupun non fisik. Tindakan secara fisik dapat berupa cubitan, pukulan, dorongan, dan lain sebagainya yang masuk dalam kategori kekerasan fisik. Sedangkan secara non fisik, dapat berupa ejekan (bullying) dan bentuk tekanan lainnya. Tindakantindakan tersebut merupakan kenakalan yang terjadi diantara anak Sekolah Dasar (SD) yang dapat menimbulkan tindakan diskriminasi.

Untuk mengatasi masalah di atas peneliti mengajukan penerapan metode pembelajaran role playing untuk meningkatkan sikap toleransi keragaman suku bangsa dan budaya. Dengan penerapan metode pembelajaran role playing diharapkan dapat meningkatkan keaktifan aktivitas siswa dalam belajar dan menunjukan peningkatan kemampuan sikap toleransi. 
B. Landasan Teori

1. Metode Pembelajaran Role Playing

a. Pengertian Metode Role Playing

Metode adalah suatu cara yang digunakan untuk mengimplementasikan rencana yang sudah disusun dalam kegiatan nyata agar tujuan yang telah disusun tercapai secara optimal, hal ini berarti metode digunakan untuk merealisasikan strategi yang telah digunakan metode memegang peran yang sangat penting dalam dunia pembelajaran. Keberhasilan implementasi strategi pembelajaran sangat tergantung pada cara guru menggunakan metode pembelajaran, karena suatu strategi pembelajaran hanya mungkin dapat diimplementasikan melalui penggunaan metode pembelajaran.

Metode pembelajaran

dikatakan efisien dan efektif apabila menghasilkan sesuatu sesuai dengan yang diharapkan. Tujuan dikatakan efisien jika penerapannya dalam menghasilkan sesuatu yang diharapkan itu relatif menggunakan tenaga, usaha pengeluaran biaya, waktu minimum, semakin kecil tenaga, usaha, biaya, dan waktu yang dikeluarkan maka semakin efisien metode itu. Perkembangan mental siswa di sekolah dasar, antara lain meliputi kemampuan untuk bekerja secara abstrak menuju konseptual. Implikasinya pada pembelajaran, harus memberikan pengalaman yang bervariasi dengan menggunakan metode yang efektif dan bervariasi. Pembelajaran harus memperhatikan minat dan kemampuan peserta didik. Salah satu metode yang digunakan dalam pembelajaran yaitu role playing.

Pembelajaran role playing menurut Hamzah (Baroroh, 2011), sebagai suatu metode yang bertujuan untuk membantu siswa menemukan jati diri di dunia sosial dan memecah dil. Hal ini berarti, melalui bermain peran siswa belajar menggunakan konsep peran, menyadari adanya peranperan yang berbeda dan memikirkan perilaku dirinya dan perilaku orang lain.

Proses bermain peran dapat memberikan contoh kehidupan perilaku manusia yang berguna sebagai sarana bagi siswa untuk: (1) menggali perasaanya, (2) memperoleh inspirasi dan pemahaman yang berpengaruh pada sikap, nilai dan persepsinya, (3) mengembangkan keterampilan dan sikap dalam memecahkan masalah, (4) mendalami mata pelajaran dengan berbagai cara. Metode role playing misalnya mengungkapkan kembali perjuangan para pahlawan kemerdekaan, keragaman suku bangsa dan budaya Indonesia, atau mengungkapkan kemungkinan 
keadaan yang akan datang, misalnya saja keadaan yang kemungkinan dihadapi karena semakin besarnya jumlah penduduk, atau menggambarkan keadaan imaginer yang dapat terjadi di mana dan kapan saja (Baroroh, 2011).

Metode Role Playing menurut Hamdani (2011:87) adalah suatu cara penguasaan bahan-bahan pelajaran melalui pengembangan imajinasi dan penghayatan siswa. Pengembangan imajinasi dan penghayatan dilakukan siswa dengan memerankannya sebagai tokoh hidup atau benda mati. Permainan ini pada umumnya dilakukan lebih dari satu orang, hal itu bergantung kepada apa yang diperankan.

Berdasarkan pendapat para ahli di atas dapat disimpulkan bahwa, Role Playing merupakan metode pembelajaran yang memberikan kesempatan kepada siswa untuk memainkan peran. Hal tersebut bertujuan untuk memperoleh pemahaman materi yang dipelajari.

\section{b. Tujuan Metode Role Playing}

Menurut Hamalik (Taniredja, 2011:40) tujuan bermain peran sesuai dengan jenis belajar adalah:

1) Belajar dengan terbuat. Para siswa melakukan peranan tertentu sesuai dengan kenyataan yang sesungguhnya. Tujuannya untuk mengembangkan keterampilanketerampilan interaktif atau keterampilan-keterampilan reaktif;

2) Belajar melalui peniruan (imitasi). Para siswa pengamat drama menyamakan diri dengan pelaku (aktor) dan tingkah laku mereka;

3) Belajar melalui balika. Para pengamat mengomentari (menanggapi) perilaku para pemain/pemegang peran yang telah ditampilkan. Tujuannya untuk mengembangkan prosedur-prosedur kognitif dan prinsip-prinsip yang mendasari perilaku keterampilan yang telah didramatisasikan; dan

4) Belajar melalui pengkajian, penilaian, dan pengulangan para peserta dapat memperbaiki keterampilan-keterampilan mereka dengan mengulanginya dalam penampilan berikutnya.

\section{c. Manfaat Role Playing}

Menurut Djamarah (Khelmi, 2016) manfaat role playing dalam proses belajar mengajar adalah:

1) Role playing dapat memberikan semacam hidden practice yaitu murid tanpa sadar menggunakan ungkapanungkapan terhadap materi yang telah dan sedang mereka pelajari;

2) Role playing melibatkan jumlah murid yang cukup banyak, cocok untuk kelas besar; dan

3) Role playing dapat memberikan kesenangan kepada siswa, karena role playing pada dasarnya adalah permainan, 
dengan bermain siswa akan merasa senang karena bermain adalah dunia siswa.

d. Kelebihan dan Kelemahan Metode Role Playing ( Bermain Peran)

Metode pembelajaran role playing memiliki kelebihan dan kelemahan yang harus diketahui oleh guru. Kelebihan metode role playing menurut Djamarah (Khelmi, 2016) adalah:

1) Siswa melatih dirinya memahami dan mengingat isi tokoh yang akan diperankan. Pemain harus memahami, dan menghayati karakter tokoh, dengan demikian daya ingat siswa harus tajam dan tahan lama;

2) Siswa akan belatih untuk berinisiatif dan berkreatif;

3) Bakat yang terdapat pada siswa dapat dikembangkan, sehingga dimungkinkan akan muncul seni drama di sekolah;

4) Kerjasama antar pemain dapat ditumbuhkan dan dibina sebaikbaiknya;

5) Siswa memperoleh kebiasaan untuk menerima dan membagi tanggungjawab dengan sesamanya; dan

6) Bahasa lisan siswa dapat dibina menjadi bahasa yang lebih baik agar mudah dipahami orang lain.

Kelebihan metode role playing menurut Hamalik (Khelmi, 2016), yaitu waktu bermain peran, siswa dapat bertindak dan mengekspersikan perasaan dan pendapat tanpa mengkhawatirkan mendapat sanksi. Bermain peran memungkinkan para siswa mengidentifikasi situasi-situasi dalam dunia nyata dan dengan ideide orang lain.

Berdasarkan pendapat di atas kelebihan bermain peran dapat disimpulkan bahwa siswa dalam proses pembelajaran akan terlatih untuk aktif, berinisiatif, dan kreatif dalam bermain peran.

Keberhasilan peran tersebut bergantung pada kegiatan yang dilakukan siswa, terutama pada analisis sebagai tindak lanjutnya. Menurut Taniredja (2011:42), metode role playing di dalam pembelajarannya selain memiliki kelebihan, metode ini juga memiliki kelemahan yaitu:

1) Bila guru tidak memahami langkah-langkah pelaksanaan metode ini akan mengacaukan kegiatan berlangsungnya role playing;

2) Memakan waktu yang cukup lama;

3) Sebagaian besar anak yang tidak ikut bermain peran mereka menjadi kurang aktif;

4) Memerlukan tempat yang cukup luas; dan

5) Kelas lain sering terganggu oleh suara pemain dan penonton.

Beberapa uraian di atas, dapat disimpulkan bahwa guru harus lebih menguasai langkah pembelajaran. Apabila pelaksanaan bermain peran mengalami kegagalan bukan saja memberi kesan yang kurang baik, 
tetapi sekaligus tujuan pembelajaran tidak tercapai.

e. Langkah-langkah Metode Role Playing (bermain peran)

Menurut Suyatno (Khelmi, 2016), metode Role Playing guru harus perhatikan langkah-langkah pelaksanaannya agar berjalan dengan baik, adapun langkahlangkah pelaksanaan metode role playing diantaranya:

1) Guru menyusun/menyiapkan karakter tokoh yang akan ditampilkan;

2) Menunjuk beberapa siswa untuk mempelajari karakter tokoh dua hari sebelum kbm;

3) Guru membentuk kelompok siswa;

4) Memberikan penjelasan tentang kompetensi yang ingin dicapai;

5) Memanggil para siswa yang sudah ditunjuk untuk melakonkan karakter tokoh yang sudah dipersiapkan;

6) Masing-masing siswa duduk di kelompoknya, masing-masing sambil memperhatikan mengamati karakter tokoh yang sedang diperagakan;

7) Setelah selesai dipentaskan, masing-masing siswa diberikan kertas sebagai lembar kerja untuk membahas;

8) Masing-masing kelompok menyampaikan hasil kesimpulannya;

9) Guru memberikan kesimpulan secara umum;

10) Evaluasi; dan

11) Penutup.
Menurut Hasibuan dan Moedjiono (Taniredja, 2011:42) langkah-langkah yang harus dilakukan dalam pembelajaran bermain peran adalah:

1) Penentuan topik dan tujuan role playing;

2) Guru memberikan gambaran secara garis besar situasi yang akan dimainkan;

3) Guru memimpin pengorganisasian kelompok, peranan-peranan yang akan dimainkan, pengaturan ruangan, pengaturan alat, dan sebagainya;

4) Pemilihan pemegang peranan;

5) Guru memberikan keterangan tentang peranan yang akan dilakukan;

6) Guru memberikan kesempatan untuk mempersiapkan diri kepada kelompok dan pemegang peranan;

7) Menetapkan lokasi dan waktu pelaksanaan role playing;

8) Pelaksanaan role playing;

9) Evaluasi dan pemberian balikan; dan

10) Latihan ulang.

Berdasarkan pendapat di atas, maka peneliti akan melakukan pembelajaran role playing dengan langkah-langkah yaitu:

1) Menentukan topik serta tujuan yang ingin dicapai;

2) Guru menyusun atau menyiapkan karakter tokoh yang akan ditampilkan; 
3) Menunjuk beberapa siswa untuk mempelajari karakter tokoh sebelum KBM;

4) Membentuk kelompok dan menentukan peran masingmasing;

5) Memberikan penjelasan tentang kompetensi yng ingin dicapai;

6) Memanggil para siswa yang sudah ditunjuk untuk melakoni karakter tokoh yang sudah dipersiapkan;

7) Setiap siswa duduk di kelompoknya, siswa memerhatikan dan mengamati karakter tokoh yang sedang diperagakan;

8) Setelah selesai dipentaskan, setiap siswa diberikan kertas sebagai lembar kerja untuk membahas;

9) Setiap kelompok menyampaikan kesimpulannya;

10) Guru memberikan kesimpulan; dan

11) Evaluasi.

Menurut Roestiyah (2012:91), ada beberapa hal yang perlu dipertimbangkan dalam melaksanakan metode pembelajaran role playing yaitu:

1) Guru harus menerangkan kepada siswa untuk memperkenalkan teknik ini, bahwa dengan metode ini siswa diharapkan dapat memecahkan masalah hubungan sosial yang aktual ada dimasyarakat, maka guru menunjuk beberapa siswa yang akan berperan, dan siswa yang lain mengamati dengan tugas-tugas tertentu pula;

2) Guru harus memilih masalah yang urgen, sehingga menarik minat anak. Guru mampu menjelaskan dengan menarik, sehingga siswa terangsang untuk berusaha memecahkan masalah itu;

3) Agar siswa memahami peristiwanya, maka guru harus bisa menceritakan sambil mengatur adegan yang pertama;

4) Bila ada kesediaan sukarela dari siswa untuk berperan, harap ditanggapi tetapi guru harus mempertimbangkan apakah tepat untuk perannya itu;

5) Bila tidak ditunjuk saja siswa yang memilih kemampuan dan pengetahuan serta pengalaman seperti yang diperankan itu;

6) Jelaskan pada pemeranpemeran itu sebaik-baiknya, sehingga mereka tahu tugas perannya, menguasai masalahnya pandai bermimik maupun dialog;

7) Siswa yang tidak turut harus menjadi penonton yang aktif;

8) Bila siswa belum terbiasa, perlu dibantu guru dalam menimbulkan kalimat pertama dialog;

9) Setelah role playing itu dalam situasi klimaks, maka harus diberhentikan, agar kemungkinan-kemungkinan

pemecahan masalah dapat disikusikan secara umum, sehingga para penonton ada 
kesempatan untuk berpendapat, menilai permainan dan sebagainya; dan

10) Sebagai tindak lanjut dari hasi diskusi, walau mungkin masalahnya belum dipecahkan.

Berdasarkan pendapat di atas dapat disimpulkan bahwa guru harus mempertimbangkan hal-hal yang penting dalam pelaksanakan metode pembelajaran role playing agar dapat mencapai tujuan pembelajaran yang diharapkan. Dalam pelaksanaan role playing guru memberikan kesempatan yang sama kepada siswa untuk memerankan tokoh yang akan diperankan.

\section{f. Kegunaan Role Playing Bagi Pembelajaran \\ Menurut \\ Setyawan \\ (2013:98), melalui role playing para siswa diharapkan dapat meraih tujuan pembelajaran sebagai berikut:}

a. Siswa mengalami situasi yang mirip dengan kehidupan sehari-hari sehingga mengetahui dan memahami peraturan, prosedur, konsep, atau permasalahan;

b. Siswa berusaha mempraktikkan atau mendemonstrasikan kemampuan atau pemahaman atas konsep; dan c. Siswa mengamati kemudian mengevaluasi tindakan di dalam role playing.

\section{Metode Penelitian}

\section{Lokasi Penelitian}

Penelitian ini dilaksanakan di SD Negeri Rahayu, yang beralamat di JIn. Sukamelang, Kecamatan Subang, Kabupaten Subang, Provinsi Jawa Barat. Penelitian dilaksanakan pada semester ganjil Tahun Ajaran 2018/2019, yaitu bulan Juli - September 2018.

\section{Desain Penelitian}

Dalam penelitian ini, rancangan penelitian yang akan dilakukan peneliti terdiri atas siklus yang berdaur ulang. Mulai dari perencanaan, pelaksanaan, pemantauan, dan merefleksikan yang bertujuan untuk memperbaiki proses pembelajaran. Siklus ini tidak hanya berlangsung satu kali, tetapi beberapa kali hingga tercapai tujuan yang diharapkan. Tiap siklus dilaksanakan sesuai dengan perubahan yang ingin dicapai, Jika dalam 1 siklus dilaksanakan sudah timbul perubahan yang baik sesuai dengan tujuan yang ingin dicapai, maka peneliti akan melakukan penelian kembali dengan siklus ke 2 agar tujuan yang diharapkan jelas tercapai. Adapun jika penelitian dalam siklus ke 2 belum ada perubahan baik, maka peneliti melakukan penelitian kembali dengan siklus yang ke 3 , begitu seterusnya sampai tujuan yang diharapkan dapat tercapai. Metode 
yang digunakan dalam penelitian ini adalah penelitian tindakan kelas (PTK). Dalam pelaksanaannya, penelitian tindakan kelas ini merujuk pada proses pelaksanaan penelitian yang dikemukakan oleh Kemmis dan MC Taggart.

Secara utuh, tindakan yang diterapkan dalam penelitian tindakan kelas seperti digambarkan dalam gambar di atas, yaitu:

a. Perencanaan (planning)

Sebelum melaksanakan PTK seorang guru hendaknya mempersiapkan terlebih dahulu konsepnya dengan membuat perencanaan dalam bentuk tulisan. Menurut Arikunto (Iskandar dan Narsim, 2015:23) mengemukakan bahwa: Perencanaan adalah langkah yang digunakan oleh guru ketika akan memulai tindakannya. Ada beberapa langkah yang dapat dilakukan dalam kegiatan ini yakni:
1) Membuat
skenario pembelajaran;

2) Membuat lembaran observasi; dan

3) Mendesain alat evaluasi.

$$
\text { Adapun kegiatan }
$$

perencanaan berdasarkan temuan awal dari identifikasi masalah yang timbul melalui orientasi, kemudian dilakukan

perencanaan pelaksanaan pembelajaran yang dikembangkan dalam proses pendidikan dalam pembelajaran ilmu pengetahuan, diantaranya:
1) Permintaan izin kepada Kepala Sekolah
SDN
Rahayu

Kecamatan Subang Kabupaten Subang Jawa Barat;

2) Permintaan kerjasama dengan guru kelas $\mathrm{V}$ SDN Rahayu Kecamatan Subang Kabupaten Subang Jawa Barat, sebagaimana dalam penelitian tindakan kelas ini guru berperan sebagai observer sekaligus informan;

3) Menyusun perencanaan pembelajaran atau skenario pembelajaran yang akan digunakan pada saat melakukan penelitian;

4) Mempersiapkan media yang diperlukan;

5) Menyusun instrumen penelitian yang akan digunakan untuk mengumpulkan data yang terdiri lembar observasi, angket siswa, dan membuat soal evaluasi;

6) Melakukan simulasi bersama serta pengamatan pembelajaran yang akan dilaksanakan; dan

7) Membuat alat evaluasi.

b. Pelaksanaan Tindakan (acting)

Tahap ini merupakan

pelaksanaan skenario pembelajaran yang telah dibuat. Dalam pelaksanaan ini harus benar-benar memahami tentang skenario pembelajaran dan langkah-langkah praktisnya. Arikunto (Iskandar dan Narsim, 2015:25) memaparkan bahwa secara rinci hal-hal yang harus diperhatikan guru antara lain:

1) Apakah ada kesesuaian antara pelaksanaan dengan perencanaan; 
2) Apakah proses tindakan yang dilakukan pada siswa cukup lancar;

3) Bagaimanakah situasi proses tindakan;

4) Apakah melaksanakan

siswa-siswa semangat; dan

5) Bagaimanakah keseluruhan dari tindakan itu.

c. Pengamatan (observing)

Kegiatan ini merupakan realisasi dari lembar observasi yang telah dibuat pada saat tahap perencanaan dan setiap kegiatan pengamatan wajib menyertakan lembar observasi sebagai bukti otentik. Pengamatan dilakukan oleh guru pelaksana yang berstatus sebagai pengamat untuk melakukan pengamatan terhadap apa yang terjadi ketika tindakan berlangsung. Data yang diperoleh dari hasil pengamatan tersebut sebagai bahan masukan dalam merefleksi hasil pembelajaran, dan hal yang menjadi penyebab tidak berhasilnya proses pembelajaran pada tindakan awal, akan diperbaiki pada tindakan selanjutnya, agar hasil dan tujuan dari pembelajaran dapat dicapai dengan maksimal sesuai yang diharapkan. Arikunto (Iskandar dan Narsim, 2015:25) mengemukakan bahwa:

1) Pengamatan dilakukan oleh orang lain, yaitu pengamat yang diminta oleh peneliti untuk mengamati proses pelaksanaan tindakan yaitu mengamati apa yang dilakukan oleh guru, siswa maupun peristiwanya; dan

2) Pengamatan dikakukan oleh guru yang melaksanakan PTK. Dalam hal ini guru tersebut harus sanggup "ngrogoh sukmo" istilah bahasa jawa yaitu mencoba mengeluarkan jiwanya dari tubuh untuk mengamati dirinya, apa yang sedang dilakukan, sekaligus mengamati apa yang dilakukan oleh siswa dan bagaimana proses berlangsung;

d. Refleksi (reflecting)

Refleksi ini merupakan sarana untuk melakukan pengkajian kembali tindakan yang telah dilakukan terhadap subjek penelitian, dan dicatat dalam pengamatan. Pada kegiatan refleksi ini, peneliti berusaha mencari alur pemikiran yang logis dalam kerangka kerja, proses, problem, isu, dan hambatan yang muncul dalam perencanaan dan tindakan yang diberikan kepada subjek.

Menurut Arikunto (Iskandar dan Narsim, 2015:26) Refleksi atau dikenal dengan peristiwa perenungan adalah langkah mengingat kembali kegiatan yang sudah lampau yang dilakukan oleh guru maupun siswa. Pada tahap ini hasil yang diperoleh pada tahap observasi akan dievaluasi dan dianalisis. Kemudian guru bersama pengamat dan juga peseta didik mengadakan refleksi diri dengan melihat data observasi, apakah kegiatan yang telah dilakukan 
dapat meningkatkan kualitas pembelajaran khususunya target yang akan ditingkatkan dalam penelitian misalnya hasil belajar, motivasi, dan aspek lainnya.

\section{Metode Penelitian}

Metode yang digunakan dalam penelitian ini adalah Penelitian Tindakan Kelas (PTK). PTK merupakan suatu penelitian yang akar permasalahannya muncul di kelas, dan dirasakan langsung oleh guru yang bersangkutan sehinngga sulit dibenarkan jika ada anggapan bahwa permasalahan dalam PTK diperoleh dari persepsi/renungan seorang peneliti (Supardi, 2016:194). Jadi, sumber masalah PTK ada pada guru kelas/guru mata pelajaran dimana mereka bertugas. Untuk itu, tidak dibenarkan seorang guru mau melaksanakan penelitian PTK, namun masalahnya minta kepada guru lain. Dengan demikian, jenis penelitian tersebut sangat bermanfaat sebagai upaya memperbaiki proses pembelajaran di kelas.

Dari uraian di atas, dapat diartikan bahwa penelitian tindakan sebagai suatu bentuk investigasi yang bersifat reflektif pertisipatif, kolaboratif, dan spiral, yang memiliki untuk penerapan tindakan (observation and evaluation), dan melakukan refleksi (reflecting) dan seterusnya sampai dengan perbaikan atau peningkatan yang diharapkan tercapai (kriteria keberhasilan).

Dalam bidang pendidikan, khususnya kegiatan pembelajaran, PTK berkembang sebagai suatu penelitian terapan. PTK sangat bermanfaat bagi guru untuk meningkatkan mutu proses dan hasil pembelajaran di kelas. Dengan melaksanakan tahaptahap PTK, guru dapat menemukan solusi dari masalah yang timbul di kelasnya sendiri, bukan kelas orang lain, dengan menerapkan berbagai ragam teori dan teknik pembelajaran yang relevan secara kreatif. Selain itu sebagai penelitian terapan, disamping guru melaksanakan tugas utamanya mengajar di kelas, tidak perlu harus meninggalkan siswanya. Jadi PTK merupakan suatu penelitian yang mengangkat masalah-masalah aktual yang dihadapi oleh guru di lapangan. Dengan melaksanakan PTK, guru mempunyai peran ganda: praktisi dan peneliti.

Merurut Supardi (2016:194), penelitian tindakkan kelas sangat menekankan pada proses dan produk, pada waktu proses tindakan berlangsung, peneliti harus merekam semua dampak dari kegiatan yang baru dilakukan. Di samping itu, PTK merupakan penelitian yang menggunakan siklus atau putaran tindakan yang berkelanjutan, maka putaran atau siklusnya minimal dua kali. Setiap putaran melalui empat tahap, yaitu: 
perencanaan, tindakan, pengamatan, dan refleksi.

McNiff (Supardi, 2016:197) menekankan bahwa tujuan utama dari penelitian tindakan kelas (PTK) adalah untuk perbaikan dan peningkatan. Kata perbaikan disini terkait dengan memiliki konteks dengan proses pembelajaran. Dan menurut Suhardjono (2016:125126) tujuan PTK adalah meningkatkan atau memperbaiki praktik pembelajaran yang dilakukan oleh guru. Tujuan-tujuan PTK di atas dapat tercapai dengan melakukan berbagai tindakan alternatif dalam memecahkan persoalan pembelajaran dikelas. Oleh karena itu, fokus PTK adalah adanya tindakan yang direncanakan, kemudian dicobakan, dan dievaluasi.

Menurut Supardi (2016:200) metode penelitian tindakan kelas dapat diartikan sebagai metode penelitian yang digunakan untuk meningkatkan atau memperbaiki dan peningkatan proses belajar mengajar di kelas. Misalnya, penelitian mengenai seringnya siswa berkelahi, seringnya siswa mengejek dan sebagainya. Berdasarkan pendapat tersebut, dapat dikatakan bahwa penelitian tentang meningkatkan nilai menghargai melalui metode penelitian tindakan kelas (PTK), termasuk penelitian ini yang ingin menguji pengaruh penerapan metode pembelajaran role playing dalam meningkatkan nilai menghargai keragaman suku bangsa pada pembelajaran IPS di sekolah dasar.

D. Hasil Penelitian dan Pembahasan

1. Aktivitas siswa Kelas V dalam pembelajaran sikap toleransi keragaman suku bangsa dan budaya dengan penerapan metode role playing

Peningkatan aktivitas siswa dapat diketahui melalui hasil lembar observasi aktivitas siswa dan peningkatan sikap toleransi siswa dapat diketahui melalui angket evaluasi yang dilakukan selama dua siklus. Aktivitas siswa dalam penelitian ini berdasarkan teori Paul B. Diedrich, teori tersebut membagi dimensi aktivitas siswa, diantaranya yaitu: visual activities, listening activities, writing activities, motor activities, mental active ties, oral activities, dan emotional activities. Data yang diperoleh berdasarkan hasil penelitian dari setiap dimensi aktivitas berdasarkan persentase pada dimensi visual activities pada siklus I yaitu $58 \%$ dan pada siklus II meningkat menjadi $92 \%$, dimensi listening activities pada siklus I yaitu $50 \%$ dan pada siklus II meningkat menjadi $100 \%$, dimensi writing activities pada siklus I yaitu $75 \%$ dan pada siklus II meningkat menjadi $100 \%$, dimensi motor activities pada siklus I yaitu 50\% dan pada siklus II meningkat menjadi $88 \%$, dimensi mental 
activities pada siklus I yaitu 50\% dan pada siklus II meningkat menjadi $100 \%$, dimensi oral activities pada siklus I yaitu $38 \%$ dan pada siklus II meningkat menjadi $75 \%$, dan dimensi emotional activities pada siklus I yaitu $58 \%$ dan pada siklus II meningkat menjadi $100 \%$.

Peningkatan aktivitas tersebut berdampak pada hasil kemampuan sikap toleransi siswa. Karena semakin siswa aktif, maka daya pemahaman mengenai menghargai keragaman suku bangsa dan budaya di Indonesia siswa akan semakin meningkat. Hal tersebut terbukti berdasarkan teori sebagaimana diungkapkan oleh Wahyuningsih dan Murwani (2015:65) "Melalui aktivitas, siswa akan dapat memahami pelajaran dari pengalamannya sehingga akan mempertinggi hasil belajarnya". Kemudian Kenan (2014:7) mengungkapkan "pentingnya aktivitas belajar dalam pembelajaran agar pemahaman pembelajaran siswa baik sehingga menghasilkan hasil belajar yang baik pula".

2. Peningkatan kemampuan sikap toleransi siswa Kelas V dengan penerapan metode role playing dalam pembelajaran

Berdasarkan hasil peningkatan aktivitas di atas, telah jelas disebutkan bahwa peningkatan aktivitas berdampak pada hasil yang diperoleh dari sikap toleransi siswa kelas $\mathrm{V}$ terhadap keragaman suku bangsa dan budaya di Indonesia menggunakan metode role playing. Kemampuan sikap toleransi keragaman suku bangsa dan budaya di Indonesia siswa dapat diketahui dari hasil pre test dan post test yang dilaksanakan pada siklus I. Pada saat dilaksanakan pre test banyak siswa masih kesulitan dalam memahami perbedaan, baik itu perbedaan agama maupun budaya. Skor Rata-rata hasil pre test yaitu 72 dengan jumlah siswa yang di bawah KKM sebanyak 14 orang siswa, sehingga dapat dinyatakan bahwa secara umum sikap toleransi siswa terhadap keragaman suku bangsa dan budaya di Indonesia masih rendah. Berbeda halnya pada post test, nilai rata-rata yang didapatkan siswa dengan menggunakan metode role playing naik menjadi 83 dengan jumlah siswa yang di bawah KKM sebanyak 4 orang siswa. Dalam hal ini meskipun belum optimal namun dapat dikatakan tuntas karena hasil persentase Ketuntasan Belajar Kelas yaitu $86 \%$. Dari hasil siklus I, peneliti melakukan refleksi dan ditindak lanjuti dalam siklus II. Hasil pre test dalam siklus II, diperoleh skor rata-rata yaitu 91 yang berarti seluruh siswa memperoleh nilai di atas KKM. Kemudian pada post test, nilai rata-rata yang didapatkan siswa dengan menggunakan metode role playing naik menjadi 96 yang berarti seluruh siswa 
memperoleh nilai di atas KKM. Sehingga persentase Ketuntasan Belajar Kelas yaitu sebesar $100 \%$ dengan kriteria sangat baik.

Dari hasil yang didapat pada siklus I dan siklus II, pada hasil perhitungan $\mathrm{N}$-Gain siklus I diperoleh indeks $\mathrm{N}$-gain 0,38 dengan kategori sedang, dan pada siklus II diperoleh indeks N-Gain 0,58 dengan kategori sedang. Sehingga dapat disimpulkan bahwa penggunaan metode role playing dalam pembelajaran terbukti memberikan pengaruh terhadap sikap toleransi keragaman suku bangsa dan budaya di Indonesia siswa kelas $\mathrm{V}$.

Data di atas memperkuat asumsi Rahyubi (2012:236) yang mengungkapkan "metode dapat digunakan oleh seorang guru untuk menggelar aktivitas belajar mengajar agar berjalan dengan baik dan sebagai jalan menuju keberhasilan dalam proses belajar mengajar". Kemudian dalam penelitiannya Basari (2013) mengungkapkan bahwa "proses pembelajaran IPS dengan penerapan metode bermain peran dapat meningkatkan karakter siswa dan secara individu tertanam kejujuran, kerja sama dan tanggung jawab untuk menyelesaikan soalsoal yang guru berikan". "Metode pembelajaran adalah cara-cara menyajikan materi pelajaran yag dilakukan oleh pendidik agar terjadi proses pembelajaran pada diri siswa dalam upaya untuk mencapai tujuan" (Sutikno, 2009:88). Maka dari itu, dalam proses pembelajaran metode adalah strategi yang sangat penting dalam memberikan informasi untuk menentukan keberhasilan yang ingin dicapai selama proses pembelajaran berlangsung. Sejalan dengan pendapat tersebut Sani (Lestari, 2018) mengungkapkan bahwa penggunaan metode sangatlah penting dalam menentukan keberhasilan suatu proses pembelajaran, semakin baik metode itu maka semakin efektif pula pencapaian tujuan, dengan demikian tujuan merupakan faktor utama dalam menetapkan baik tidaknya penggunaan suatu metode. Dengan demikian, teori metode menurut rahyubi jika dikaitkan dengan pendapat Basari dapat memperkuat hasil penelitian ini bahwa penggunaan metode role playing memberikan pengaruh terhadap sikap toleransi siswa.

Terbuktinya metode role playing memberikan pengaruh terhadap sikap toleransi keragaman suku bangsa dan budaya di Indonesia siswa kelas $\mathrm{V}$ sekolah dasar. Berdasarkan teori belajar Piaget, menjelaskan bahwa kemampuan berpikir atau taraf berpikir siswa sekolah dasar (kelas V) adalah operasional konkret, dimana dalam memahami suatu konsep materi pelajaran siswa kelas $\mathrm{V}$ harus diberikan kegiatan yang berhubungan dengan benda nyata atau kejadian nyata yang 
dapat diterima akal mereka Piaget (Ibda, 2015:35). Dengan demikian, teori belajar menurut Piaget dapat memperkuat hasil penelitian ini bahwa penggunaan metode role playing memberikan pengaruh terhadap sikap toleransi keragaman suku bangsa dan budaya di Indonesia siswa kelas V.

Dari pendapat para ahli di atas menguatkan hasil penelitian yang dilakukan, hasil dari penelitian yang telah dipaparkan sebelumnya bahwa nilai aktivitas siswa dan sikap toleransi keragaman suku bangsa dan budaya di Indonesia siswa kelas $\mathrm{V}$ menggunakan metode role playing mengalami peningkatan.

\section{E. Kesimpuan}

Berdasarkan data hasil penelian tindakan kelas mengenai penggunaan metode role playing dalam pembelajaran IImu Pengetahuan Sosial (IPS) di kelas V SD Negeri Rahayu dapat disimpulkan bahwa:

1. Secara umum aktivitas siswa kelas $\mathrm{V}$ dalam pembelajaran IPS mengenai sikap toleransi keragaman suku bangsa dan budaya di Indonesia dengan menggunakan metode role playing mengalami perkembangan positif. Hal ini didasarkan pada data rata-rata aktivitas siswa siklus I yaitu $56 \%$ dan pada siklus II meningkat menjadi $90 \%$.
2. Secara umum sikap toleransi siswa kelas $\mathrm{V}$ dalam pembelajaran IPS mengenai sikap toleransi keragaman suku bangsa dan budaya di Indonesia dengan menggunakan metode role playing mengalami perkembangan positif. Hal ini didasarkan pada data N-Gain pada siklus I yaitu 0,38 dan pada siklus II meningkat menjadi 0,58. Adapun data persentase ketuntasan kelas pada siklus I yaitu $86 \%$ dan pada siklus II meningkat menjadi $100 \%$.

Data tersebut membuktikan bahwa metode role playing memberikan pengaruh terhadap sikap toleransi keragaman suku bangsa dan budaya di Indonesia siswa Kelas V.

\section{DAFTAR PUSTAKA}

Abidin, Y. (2014). Desain Sistem Pembelajaran Dalam Konteks Kurikulum 2013. Bandung: PT Refika Aditama, hlm.1

Ahmadi. (2011). Strategi Pembelajaran Sekolah Terpadu. Jakarta: PT. Prestasi Pustaka, hlm. 54

Anshori, S. (2014). Kontribusi IImu Pengetahuan Sosial Dalam Pendidikan Karakter. [Online]. Tersedia:

Syekhnurjati.ac.id/jurnal/index.php/ edueksos/article/download/363 /316. [7 Mei 2018]

Arikunto, S. (2010). Prosedur Penelitian Suatu Pendekatan Praktek. Jakarta: Rineka Cipta, hlm. 211 
(2012). Prosedur Penelitian Suatu Pendekatan Praktek. Jakarta: Rineka Cipta, hlm. 203

(2013). Prosedur Penelitian Suatu Pendekatan Praktek. Jakarta: Rineka Cipta, hlm. 194

Aunurrahman. (2011). Belajar dan Pembelajaran. Bandung: Alfabeta, hlm. 58

Aqib, Z. (2009). Penelitian Tindakan Kelas. Bandung: CV Yarma Widya, hlm. 41

Baroroh, K. (2011). Upaya Meningkatkan Nilai-Nilai Karakter Peserta Didik Melalui Penerapan Metode Role Playing. [Online]. Tersedia:

https://journal.uny.ac.id/index.php/j ep/article/view/793. [6 Juni 2018]

Basari, A. (2013). Meningkatkan Karakter Dan Hasil Belajar Ips Menggunakan Metode Bermain Peran Pada Siswa SD. [Online]. Tersedia:

https://journal.uny.ac.id/index.php/j pe/article/view/2629. [6 Juni 2018]

Daryanto dan Suryatri. (2013). Implementasi Pendidikan Karakter di Sekolah. Yogyakarta: Gava Media, hlm. 70, hlm. 145

Gunawan, R. (2016). Pendidikan IPS. Bandung: Alfabeta, hlm. 17, hlm. 18, hlm. 51

Hamalik, O. (2008). Kurikulum dan pembelajaran. Jakarta: Bumi Aksara, hlm. 57

Hamdani. (2011). Strategi Belajar Mengajar. Bandung : Pustaka Setia, hlm. 87, hlm. 140

Hanafiah, dan Suhana. (2010). Konsep Strategi Pembelajaran. Bandung: PT Refika Aditama, hlm. 23
Ibda, F. (2015). Perkembangan Kognitif: Teori Jean Piaget. Bandung: Alfabeta, hlm. 35

Iskandar, D. dan Narsim. (2015). Penelitian Tindakan Kelas dan Publikasinya. Cilacap: Ihya Media, hlm. 23, hlm. 25, hlm. 26

Kartika, E. (2017). Peningkatan Sikap Menghargai Pendapat dan Prestasi Belajar Menggunakan VCT. [Online]. Tersedia:

http://repository.ump.ac.id/4150/3/ Enggar\%20Kartika\%20Sari_B AB\%20ll.pdf. [20 Mei 2018]

Kenan, (2014), Upaya Peningkatan Aktivitas Belajar Siswa Melalui Penerapan Metode Penugasan Pada Materi Pokok Menulis di Kelas IV SDN 050649 Simpang Pulau Rambung. [Online]. Tersedia:

https://anzdoc.com/jurnalsaintech-vol-no02-juni-2014issn-no.html [10 Agustus 2018].

Khelmi, D. (2016). Upaya Meningkatkan Sikap Menghargai Prestasi Melalui Penerapan Metode Role Playing. [Online]. Tersedia:

http://repository.ump.ac.id/2052/3/

Dea\%20Khelmi\%20Fahriani_B $A B \% 20 I I . p d f$. [8 Juni 2018]

Kurniawan, A. (2013). Manager dan Supervisior. Yogyakarta: Buku Pintar, hlm. 132

Kusumah, W. dan Dwitagma, D. (2010). Mengenal Tindakan Kelas. Jakarta: Indeks, hlm. 71

Lestari, N. D. (2018). Pentingnya Penggunaan Metode Dalam Proses Pembelajaran. [Online]. Tersedia:

https://www.academia.edu/352385 33/PENTINGNYA_PENGGUN AAN_METODE_DALAM_PRO 
SES_PEMBELAJARAN

Oktober 2018)

Listanti, A. (2016). Analisis Tindakan Diskriminasi Peserta Didik Di Sekolah

Dasar. [Online]. Tersedia:

http://repository.ump.ac.id/2198/2/

ANALISA $\% 20$ LISTANTI\% $20 \%$ 3D\%20BAB\%20I.pdf. [7 Mei 2018]

Majid, A. (2014). Pendidikan Berbasis Ketuhanan. Bogor: Ghalia Indonesia, hlm. 4

Meliana, I. (2015). Pengaruh Metode Contoh Bukan Contoh (Examples Non Examples) Terhadap Kemahiran Menulis Teks Berita Siswa Kelas VIII Sekolah Menengah Pertama Negeri 17 Bintan Tahun Pelajaran 2014/2015. Tanjung Pinang: Fakultas Keguruan Dan IImu Pendidikan Universitas Maritim Raja Ali Haji. [Online]. Tersedia: http://jurnal.umrah.ac.id/wpcontent/uploads/gravity_forms/l ec61c9cb232a03a96d0947c64 78e525e/2015/08/EJOURNALIIS-MEILIANA-110388201049FKIP2015PDF.pdf [7 Mei 2018] Mudyahardjo, R. (2002). Pengantar Pendidikan. Jakarta: Rajawali Pers, hlm. 6

Natawijaya, R. (2005). Aktivitas Belajar. Jakarta: Depdiknas, hIm. 45

Pagappong, $\quad$ Y. (2015). Peningkatan Disiplin Kerja Pegawai Pada Kantor Kelurahan Harapan Baru Kecamatan Loa Janan Ilir Samarinda Seberang. [Online]. Tersedia: http://ejournal.ip.fisipunmul.ac.id/site/wpcontent/uploads/2015/03/JUR
NAL\%20Rian\%20(03-26-1501-45-47).pdf. [20 Mei 2018]

Purwanti, E. (2016). Penggunaan Metode pengajar Role Playing Pada Pembelajaran IPS di Kelas IV. [Online]. Tersedia:

http://repository.unpas.ac.id/14067/ 6/BAB\%20II.docx. [24 Mei 2018]

Purwanto. (2009). Evaluasi Hasil Belajar. Yogyakarta: Pustaka Belajar, hlm. 45, hlm. 48, hlm. 49, hlm. 51, hlm. 52

(2010). Evaluasi Hasil Belajar. Yogyakarta: Pustaka Belajar, hlm. 112

Putra, W. (2007). Strategi Belajar Mengajar. Jakarta: Universitas Terbuka, hlm. 19

Rahyubi, H. (2012). Teori-teori Belajar dan Aplikasi Pembelajaran Motorik. Bandung: Nusa Media, hlm 236

Ridwan. (2004). Belajar Mudah Penelitian untuk GuruKaryawan dan Peneliti Pemula. Bandung: Alfabeta, hlm. 71

Roestiyah. (2012). Strageti Belajar Mengajar. Jakarta: Rineka Cipta, hlm. 91

Sadulloh, U. (2015). Pengantar Filsafat Pendidikan. Bandung: Alfabeta, hlm. 55

Sagala, S. (2009). Konsep dan Makna Pembelajaran. Bandung: Alfabeta, hlm. 16

(2014). Konsep dan Makna Pembelajaran. Bandung: Alfabeta, hlm. 33, hlm. 37

Salahuddin, A. dkk. (2013). Pendidikan Karakter. Bandung: Pustaka Setia, hlm. 42, hlm. 43

Sanjaya, W. (2009). Strategi Pembelajaran Berorientasi Standar Proses Pendidikan. Jakarta: Prenada, hlm. 112 
Saptono. (2011). Dimensi-Dimensi Pendidikan Karakter:

Wawasan, Strategi, dan Langkah Praktis. Jakarta: Esensi, hIm 133

Sardiman, A. M. (2011). Interaksi dan Motivasi Belajar Mengajar. Jakarta: Rajawali Press, hlm. 100

(2014). Interaksi dan Motivasi Belajar Mengajar. Jakarta: Rajawali Press, hal. 101

Setyawan, S. (2013). 20 Metode Mengajar Dan Aplikasinya. Jakarta: PT Grasindo, hlm. 98

Sudjana. (2005). Metoda Statistika. Bandung: Tarsito, hlm. 67

Sugiyono. (2007). Metode Penelitian Kuantitatif, Kualitatif, dan R\&D. Bandung: Alfabeta, hlm. 108

(2014). Metode Penelitian Kuantitatif, Kualitatif, dan R\&D. Bandung: Alfabeta, hlm. 207

(2017). Metode Penelitian Kuantitatif, Kualitatif, dan R\&D. Bandung: Alfabeta, hlm. 142, hlm. 145, hlm. 224, hlm. 244

Suhada, I. (2017). Perkembangan Peserta Didik. Bandung: PT Remaja Rosdakarya, hlm. 51, hlm. 52

Supardi. (2016). Penelitian Tindakan Kelas. Jakarta: Bumi Aksara, hlm. 194, hlm. 197, hlm. 200

Suhardjono. (2016). Penelitian Tindakan Kelas. Jakarta: Bumi Aksara, hlm. 125, hlm. 126

Supinah dan Parmi. (2011). Pengembangan Pendidikan Budaya dan Karakter Bangsa Melalui Pembelajaran Matematika di SD. Jakarta: Kemendiknas. hlm. 23

Susanto, D. A. (2013). Teori Belajar dan Pembelajaran di Sekolah
Dasar. Jakarta: Prenadamedia Group, hlm.19

Sutikno, S. (2009). Belajar dan Pembelajaran. Bandung: Prospect, hlm. 88

Suyadi. (2013). Strategi Pembeljaran Pendidikan Karakter. Bandung: PT Remaja Rosdakarya, hlm. 8

Taniredja, T. (2011). Model-Model Pembelajaran Inovatif. Bandung: Alfabeta, hlm. 40, hlm. 42

Undang-Undang Republik Indonesia. No. 20 Tahun 2003 Tentang Sistem Pendidikan Nasional dan Penjelasannya. Pen: CV Aneka IImu, Cet 1 Tahun 2003

Usman, H. (2011). Manajemen Teori, Praktis, dan Riset Pendidikan. Jakarta: Bumi Aksara, hlm. 6

Wahyuningsih, D \& Murwani, S. (2015). Peningkatan Aktivitas Dan Hasil Belajar Siswa Pada Pembelajaran Biologi Melalui Implementasi Model Numbered Head Together Pada Siswa Kelas Xi Sma Negeri 2 Yogyakarta. [Online]. Tersedia:

http://download.portalgaruda.org/ar ticle. php?article $=390046 \& \mathrm{val}=$ 447\&title=PENINGKATAN\%20 AKTIVITAS\%20DAN\%2OHASI L\%20BELAJAR\%20SISWA\%2 OPADA\%2OPEMBELAJARAN $\% 20 B I O L O G I \% 20 M E L A L U I \% 2$ OIMPLEMENTASI\%20MODEL $\% 20 N U M B E R E D \% 20 H E A D \%$ 20TOGETHER\%20PADA\%20 SISWA\%2OKELAS\%20XI\%20 SMA\%20NEGERI\%202\%20Y OGYAKARTA [13 Maret 2018]. Wibowo. (2012). Manajemen Kerja. Jakarta: Raja Grafindo Persanda, hlm. 23, hlm. 34 
Widoyoko, E. P. (2016). Evaluasi

Program Pembelajaran.

Yogyakarta: Pustaka Belajar, hlm. 237

Wilis, R. (2011). Teori-Teori Balajar dan Pembelajaran. Bandung: Erlangga, hlm. 2

Yaumi, M. (2014). Pendidikan Karakter: Landasan, Pilar, dan Implementasi. Jakarta: Prenadamedia Group, hlm. 90, hlm. 91, hlm. 92 